Review scientific article Received 22.04.2018.

Approved 10.05.2018.

\title{
THE IMPACT OF THE RELATIONS BETWEEN THE UNITED STATES OF AMERICA AND RUSSIAN FEDERATION ON SERBIA'S EU ACCESSION ${ }^{\star *}$
}

Economic crisis, financial deficit, problems with the energy policy, Greek crisis, the referendum in the UK, a common foreign and security policy and its own deficiencies, the migrant crisis, and the fact that Europe faces terrorism on its territory are just some of the issues that take a lot of political attention and energy of political elites in Europe. All these issues have reached their peak in Serbia.

Moreover, Serbia finds itself in the middle of the foreign policy competition between the great powers, such as the United States of America and the Russian Federation. Exhausted by economic and internal political issues, Serbia is to create and focus on its own foreign policy goal and stay on its path until the final destination - complete economic and social recovery of the country.

Keywords: Republic of Serbia, foreign policy, economy, politics, European Union, the United States of America, Russian Federation, security issues, national security strategy

Geoeconomic Faculty, Megatrend University, Belgrade, Serbia; vasic_ljubica@yahoo.com

** This paper was presented in English language at the IV International Forum at the Geoeconomic Faculty, Megatrend University, February $19^{\text {th }} 2018$ 


\section{Context}

In order to better grasp the relations between the USA and Russia we could employ the deductive theory in the international relations. Consequently, the path from an inductive approach to deductive theory goes through the development of the concept of the structure of the international policy system, accepted by all the participants of the discussion that is the subject of nowadays discussions, although they do not carry out the same assumptions. According to contemporary approach, international politics is understood as a system composed of two levels, a structural level and a level of states; and these two levels are interacting. Briefly speaking, the structure is a set of constraining conditions. The structure of the international policy system determines: the principle of organizing system management or anarchy contrary to the hierarchy, the principle by which power is organized within states, which implies a functional differentiation of parts of the system, formal relations of superiority and subordination or division into legislative, executive and judicial governments, which results in a functional similarity of units (survival of security is the basic function of states); the distribution of capabilities between the basic system units. These two structural elements are, at the same time, the sources of structural change. ${ }^{1}$ Both levels have served these two world forces on their path towards the strengthening their position on the world scene, either using the hard or soft power.

Needless to say that today's debates could have two sub-levels. The first sub-level would be the evaluation of the state and prospects of direction of transatlantic relations. The second sub-level would refer to searching the limits and potential of transatlantic leadership in creating impelling governance structures. One of the possible implementations of the debates would be led in three steps. The first one involves researching and reorganizing theory and history in order to understand the transatlantic relations. The second one could mean to follow the factors that might make an impact on the relationship between the United States, Europe and Russia, on a different road. The focal point should be on domestic indicators of change, with an emphasis on the inferences for transatlantic relations of European integration and the evolution of the US foreign policy. Further on, our analysis could focus on how the USA and Europe have approached the emerging powers, particularly Russia. ${ }^{2}$ The third one is to determine the transatlantic relations in the context of the global shift of power. One potential discovery is that the world of the twenty-first century demonstrates different power configurations in different policy domains. This dynamic change in structure of power refines the exercise of leadership. Aside

Schulzinger, Robert D. (2008): U.S. Diplomacy since 1900, Oxford University Press, New York, Sixth Edition, p. 356-371

2 Vukadinovic, Radovan (2010): Balkan u Ruskoj politici, Rusija i Zapadni Balkan, Friedrich Ebert Stiftung, Sarajevo, p. 5-19 
from power and authority, leadership requires moral persuasion, all necessary strategies to build alignments. Soft power is needed for employing the pressure and encouraging pragmatic engagement, and especially for managing conflicts between great powers.

The importance of Russian-American relations, which has always affected world events, the recovery of Russia after the Cold War, the US attempts to maintain peace in the world and their fight against terrorism are enough to see this topic from a broader perspective. At the end of 1991, the disintegration of the territorially largest country in the world created a void in the very center of Eurasia.

For the United States, this new geopolitical situation was the greatest challenge and opportunity for the creation of a unipolar world, an opportunity that was not used in the right way. The first task was to prevent the emergence of political anarchy, and a long-term task - economic recovery and democratic transformation of Russia and avoiding the creation of a new empire that could jeopardize US geostrategic goals. Russian-American relations can be viewed on several levels, but it is certainly true that the international dimension remains the main analytical compound of any analysis. Russia and the US are not directly opposed to each other, as it seems at first, but as the strongest, they only want "their pieces of cake", which is proportionate to their strength. ${ }^{3}$

The United States has viewed a democratic and prosperous Serbia, at peace with its neighbors and integrated into Euro-Atlantic institutions, as an important part of its key policy goal of a Europe "whole, free, and at peace." Recognizing that Serbia is an important political and economic factor in the overall future of the Western Balkans and that the United States has provided a sizable amount of assistance to Serbia, Congress may want to focus more specifically on U.S. relations with Serbia, its role in the Western Balkans, Serbia's EU membership negotiations, and Serb-Russia relations, particularly the operation of the Russian facility in Nis and Russian support for pro-Moscow political parties in Serbia.

Nowadays discussions could contribute to the completion of the NATO system, the US global policy in the areas of sustainable development, the history of the US-Europe relations on these essential issues of general social progress, as well as the world community, represented in the UN, predicting the possibility of attaining the goals of sustainable development. ${ }^{4}$

Morelli, L. Vincent (2018): “Serbia: Background and U.S. Relations”, Congressional Research Service, CRS Report prepared for Members and Committees of Congress, Washington D.C., 7-5700, 2018, p. 1-7

4 "NATO-Russia Relations: The Facts." October 26, 2017. https://www.nato.int/cps/en/ natohq/topics_111767.htm 


\section{Social significance of today's debates-Serbia and USA-Europe relations}

The social significance of today's many debates is to acquaint Serbian and American society, and the wider professional and scientific public, with various world experiences, followed by NATO programs in the areas of sustainable development, that is, through the policies and attitude of the NATO as a global factor in the process of achieving the goals of a sustainable development, ${ }^{5}$ in order to transform these experiences, knowledge and best practices in all relevant areas in the Republic of Serbia. Serbia, as a UN member and signatory of the relevant international documents, should be very interested in this issue, the ways of functioning and financing, the possibility of direct contribution to investments and the work of NATO agencies, their results in all areas of analyzed work - and on their own territory. Some of the areas of sustainable development of significance, applicable in the territory of the Republic of Serbia, are:

- protection and improvement of the environment;

- migration of refugees;

- internally displaced persons and migrant workers - caused by armed conflicts;

- poverty or unemployment (especially young people and the professionals in the country);

- the level of health care of the population, as well as the prevention of diseases with a high mortality rate;

- modern education and eradication of illiteracy - raising the educational level of citizens;

- problems in energy sector;

- procurement, transfer and adoption of modern techniques and technologies;

- strengthening of the democratic institutions, processes and practices, respecting and protecting human rights, and especially vulnerable categories of the population.

The problem which has unquestionably slowed down these processes is the economic crisis that has deeply affected the countries in the Balkans. There was a significant deceleration of the initiated reforms and the drop of the foreign direct investments and the deceleration of the economic growth resulted in a deepening of the budget and the balance of payments deficit. There were new loans from the IMF (Serbia and Bosnia and Herzegovina). The governments of these countries, faced with the crisis, were neglecting the work on systemic reforms related to meeting the European Union criteria. At the same time, a significant deterioration in living standards became more noticeable, which

Wallin, Matthew (2017): American Security project, "U.S. Foreign Policy Towards Russia (An Overview of Strategy and Considerations)", White paper, Washington D.C., p. 10-19 
enhanced the trend of the population having the negative attitude towards the necessary reforms. ${ }^{6}$

Despite these negative trends, all the governments in the region are clearly determined that in the coming years they would continue with the reforms. Fulfilling the proclaimed attitudes, the conditions for visa liberalization were met, and there was a significant progress in the field of regional cooperation (mainly between Serbia, Croatia, and Bosnia and Herzegovina) with a successful fight against corruption in Croatia and organized crime in Serbia. However, there are still obstacles of the Balkan countries on their path to the European Union such as: high inefficiency of the judicial system, weak state institutions, the inadequate administrative potential necessary for the current preparation and implementation of the reforms, as well as the political instability.

From the foregoing, it is not realistic to expect rapid and significant improvements in the areas that the EU has designated as critical. The task of the Balkan countries and the task of the European Union itself is to solve the existing problems together and to make this region more stable and economically prosperous.

The transfer of power that took place in Belgrade in October 2000 cleared only one part of the road towards the political and economic transition of Serbia, thus allowing the reshaping of the foreign policy model which had long been a turning point for Serbia. The new area of cooperation between Serbia and the European Union was announced. From the very beginning of the process of bringing Serbia closer to the European Union, the European Commission carefully followed the progress of Serbia on its path towards the EU.

The matrix by which Serbia is led on its way towards the European Union is based on the guidelines clearly defined by European association agreements in cooperation with the countries of Central and Eastern Europe which are concluded according to the same pattern designed for all member countries. However, the nuances are evident in terms of the layout of the phases in the liberalization of trade, and they differ because of the fact that the agreements were not signed at the same time. The agreements are made from the preamble and their titles are the following:

1. Political dialogue;

2. Free movement of goods (sections: industrial products, agriculture, fishing, and general provisions);

3. The labor movement, the creation of businesses;

4. Payments, capital, competition and other economic provisions, approximation of laws;

5. Economic cooperation;

$6 \quad$ Grbic, Vladimir (2005): Ekonomija Evropske Unije, Megatrend Univerzitet Primenjenih Nauka, Beograd, p. 265-270 
6. Cultural cooperation, financial cooperation and institutional provision, general and final provisions.

The geopolitical position of Serbia is such that it would not need to seek for an alternative, which is due to the growing trend of creating economic and political regions, partly because of the lack of resources that can improve the accumulation of monetary potential. Serbia's entry into the European Union is an important national strategic goal. Of course, diversification of the partners is necessary, and in the era of globalization, this approach is perfectly normal and common. Membership in the European Union provides opportunities for economic development and offers instruments for creating a legal state, but nothing happens without the efforts of Serbia itself to turn these benefits into practice. The state itself should be both a regulator and stimulant.

Viewed in a long-term, the EU convergence process, the process of modernization, as well as Serbia's integration into European society, does not have a serious alternative. In addition, it is also necessary to adapt to the process of European integration, not only for the mere fact of actually becoming a member of the EU, but because of the possibility of recuperating the society by following clear guidelines. Examples of economic decline of Serbia, in comparison with its immediate neighbors, delineate the most obvious argument for the thesis that our country loses a lot (in the economic, strategic, technological, political and other domains) due to its slowness to adapt to the changed international political and economic circumstances. Only competent Serbian government can create positive conditions for private investments, and additionally lobby for certain projects through representative offices abroad.

It is believed that Serbia's attention should be focused on education so that the offer of the resources can be expanded. In order to become a member, Serbia should adjust its economic, legal and social system to the European regulations, including the implementation of EU regulations. On that road, it is necessary to attract the old members, who will not easily accept the situation after all that has been said about Serbian people and the global economic crisis. Therefore, we must be prepared for this along the way.

\section{Military neutrality and cooperation with NATO}

Serbia is a military neutral country based on the resolution of the Serbian National Assembly in December 2007. The resolution delineated that the National Assembly decided to proclaim the military neutrality of the Republic of Serbia in relation to the existing military alliances until achievable referendum is called upon to reach a final decision on the matter. The elaboration of military neutrality in relation to which type of (new) tasks and what level of equipping 
such an external political position imposes on the armed forces of the Republic of Serbia, apart from the obvious clause on NATO's non-accession, is absent. The national security strategy does not recognize neutrality among the basic definitions, goals and principles of national security policy. Self-proclaimed military neutrality that did not receive materialization in the form of consequent security sector reforms has made it an empty mark in which political actors have, since $2007,{ }^{7}$ provided the content that suited them. Thus, since then, Serbia has deepened and institutionalized its cooperation with NATO, given the implementation of the Accession of the Partnership for Peace Program in 2006 in the form of participation in the Integration Program, in the Planning and Review Process, the existence of the NATO Serbia Group for the Defense System Reform, the opening of the military mission of the Republic of Serbia to NATO in 2010, and the establishment of a NATO Military Liaison Office in Belgrade. Serbia concludes with the adoption of the Individual Partnership Action Plan (IPAP) in 2015 and the Parliamentary Decision on the Confirmation of the Agreement on Cooperation in the Field of Logistics and the Regulation of the Status of NATO Forces in the territory of Serbia in 2016, completing the cooperation with NATO so far. ${ }^{8}$

There are opinions that the European missile defense project must be planned and implemented as a purely joint venture by the US, the Russian Federation and the North Atlantic Treaty Organization. The mutual cooperation between NATO and the Russian Federation on the missile defense is observed as a necessity and as the most important segment of achieving stability of the EuroAtlantic Security Community, a concept defined by the document Euro-Atlantic Security Initiative. According to the distinguished team of experts, led by the former US department of Defense, successful cooperation on missile defense can be accomplished by any factor if:

a) they share mutual perception of security threats against which the missile defense system is organized; believe that the threat is realistic and believe that it is in their national interest to oppose the threat to missile defense;

b) they do believe that cooperation will be realistically achieved and realized;

c) the missile defense cooperation should contribute to reducing the existing tensions and doubts with partners involved in the process. From such a theoretical model, this team offers a concrete form of cooperation on the NATO-Russia Federation's relationship with the European missile shield. Its fundamental features should be the following: the establishment of the US/NATO/Russian Federation joint operational centers for information gathering and information related to potential threats to the missile defense plan. Further selection and analysis of information gathered within the US/

http://www.parlament.gov.rs/ostala-akta/doneta-akta/u-sazivu-od-14-februara-2007.1040.html

8 Strbac, Katarina (ed.) (2010): Security and Defense Aspects of Serbia's Accession to the European Union, Institute for Strategic Research, Belgrade, p. 76 
NATO/Russian Federation's joint command and control centers will contribute to gathering transparency of the international environment from which threats are treated, but also more effective detection of missile attacks worldwide;

d) there is respect for territorial sovereignty and territorial integrity of all sides. Namely, in case of a missile attack, each actor would be defending independently, but cooperation in the exchange of information would contribute to the defense;

e) aware of the current discrepancy between technical and material relations between the two partners, NATO and the Russian Federation should commit themselves to reducing the gap in the future and equally bear the material and technical burden of the joint engagement;

f) this cooperation project originally refers to missiles ranging up to $4500 \mathrm{~km}$, and in the future phases of cooperation would include larger range missiles. The proposed plan is much more concrete than the jointly adopted Declaration at the NATO Summit in Lisbon. Greater involvement of the Russian Federation in issues related to the European defense shield would open the door to a higher degree of cooperation of the overall relations between United States and the Russian Federation. ${ }^{9}$

Russia and the Balkans have had a special place in the foreign policy strategy as a sphere where Russia can fulfill its interests. The territory of the Balkans, in accordance with the cultural, religious and political ties, was the contiguous part of Europe to Russia, and thus, Russian interest primarily in the suppression of Turkish interests, and later the interest of the West, made its territory more than interesting for solid Russian activities. Serbia represents a kind of Russian oasis in the Western Balkans. It is by no chance that it is the only one of all Eastern European countries that continually expresses friendship with Moscow and seeks help from it. Factors such as history, orthodoxy, and economic ties gave Russia the access to be a part of Yugoslavia, at the time of the collapse of Yugoslavia, and in support of Serbia, it is trying to stop NATO settling in Serbia and strengthening Euro-Atlantic relations. Serbia is an active member of the NATO Partnership for Peace Program, but since 2006, when the National Assembly came to a decision to proclaim military neutrality, not wanting to dominate a full membership in the Alliance. It is unlikely that some other Western Balkan country will follow that path and slow down its approach to NATO. However, the fact is that Serbia broke the homogeneity of the Western Balkans region regarding the expansion of NATO. In the Western Balkans, Moscow is not directly confronted with NATO. It was aware that the next round of NATO expansion

$9 \quad$ Ischinger, Wolfgang, Igor Ivanov and Sam Nunn (2010): "Missile Defense: Toward a New Paradigm”, Working Group Paper ESIA Working Group on Missile Defense Report, Washington D.C., p. 5-10 
would certainly happen in the region. In military terms it was striving to be present in the countries of the region regarding the settlement of clearing liability of the former SFRY and the replacement of military equipment and weapons of the Soviet region. ${ }^{10}$

\section{Final remarks and policy implications}

The lack of a foreign political strategy, and non-existing consensus on the strategy of foreign policy prevents a consistent and predictable security policy. According to the 2007 resolution, self-proclaimed, but undefined military neutrality served as an excuse for waiving responsibility from formulating a comprehensive policy that envisions key values which represent means to defending them. The development of foreign political and security dualism in cooperation with both NATO and Russia, with the unambiguous ambition of joining the EU as the first goal of foreign policy, enabled political actors to enter the content that suits them in the "military neutrality". The expected adoption of the new National Security Strategy is an opportunity for the political elites in the government to offer a consistent and predictable Serbian security policy and set requirements for security sector actors who need to respond to the set of goals and tasks. The least to be insisted on is the process of drafting the new Strategy, unlike the 2009 process, that would enable the participation of a wide range of actors, from traditional security sector factors to those who, under the Constitution and relevant laws, exercise control over them (parliament, courts, independent state institutions), to civil society organizations and research organizations that each, in the domain of their work, can contribute to the creation of a document based on consensus and mutual understanding as to who and what is protected by the Republic of Serbia. The narrative of the future Strategy can tell us how we understand security in the potential conflict of the various narratives that Serbia belongs to.

\section{Conclusion}

- One of the most important tasks of the newly formed government should be the development of the foreign policy strategy of the Republic of Serbia, with which the National Security Strategy should be harmonized.

- Ensuring an open and transparent process of drafting of a new National Security Strategy with the involvement of a wide range of participants (state

$\overline{10}$ Djukic, Srecko (2015): “OdnosiSrbijesaRusijom - Osvrtnaposjugoslovenski (postsovjetski period)”, p. in:JelicaMinic(ed.),Izazovispoljnepolitike, Zbornikradova, Friedrich Ebert Stiftung, EvropskipokretSrbija, Beograd, p. 31-37 
factors in the security sector, independent state institutions, civil society organizations, universities).

- It is necessary to define a predictable and clear security policy and to coordinate further reform of the security sector in order to respond to the given objectives.

\section{Literature}

- Cohen, J. Lenard\& John R. Lampe (2011): Embracing Democracy in the Western Balkans: From Post-Conflict Struggles toward European Integration, Woodrow Wilson Press, Washington, D.C.

- Djukic, Srecko (2015): “OdnosiSrbijesaRusijom - Osvrtnaposjugoslovenski (postsovjetski period)”, p. in: JelicaMinic(ed.), Izazovispoljnepolitike, Zbornikradova, Friedrich Ebert Stiftung, EvropskipokretSrbija, Beograd

- Grbic, Vladimir (2005): Ekonomija Evropske Unije, Megatrend Univerzitet Primenjenih Nauka, Beograd

- Iscinger,Wolfgang,IgorIvanov and Sam Nunn (2010): “Missile Defense: Toward a New Paradigm", Working Group Paper ESIA Working Group on Missile Defense Report, Washington D.C.

- John J. Mearsheimer (2001): The Tragedy of Great powers Politics, W. W. Norton \& Company, Inc., New York

- Morelli, Vincent L. (2018): "Serbia: Background and U.S. Relations", Congressional Research Service, CRS Report prepared for Members and Committees of Congress, Washington D.C., 7-5700, 2018

- "NATO-Russia Relations: The Facts." October 26, 2017; https://www.nato. int/cps/en/natohq/topics_111767.htm

- Schulzinger, Robert D., (2008): U.S. Diplomacy since 1900, Oxford University Press, New York, Sixth Edition

- Strbac, Katarina, (ed.) (2010): Security and Defense Aspects of Serbia's Accession to the European Union, Institute for Strategic Research, Belgrade

- Vasic, Ljubica (2014): "EU enlargement and Serbia's foreign policy challenges", World of Diplomacy: Journal of the Ministry of Foreign Affairs of the Republic of Azerbaijan, 37/2014

- Vukadinovic, Radovan, (2010): Balkan u Ruskoj politici, Rusija i Zapadni Balkan, Friedrich Ebert Stiftung, Sarajevo

- Wallin, Matthew, (2017): American Security project, "U.S. Foreign Policy Towards Russia (An Overview of Strategy and Considerations)", White paper, Washington D.C.

- http://www.parlament.gov.rs/ostala-akta/doneta-akta/u-sazivu-od-14februara-2007.1040.html 


\section{UTICAJ ODNOSA IZMEĐU SJEDINJENIH AMERIČKIH DRŽAVA I RUSKE FEDERACIJE NA PRISTUPANJE SRBIIJE EU}

Ekonomska kriza, finansijski deficit, problemi sa energetskom politikom, grčka kriza, referendum u Velikoj Britaniji, zajednička spoljna $i$ bezbednosna politika, $i$ sopstveni nedostaci unutar Evropske unije, te migrantska kriza i činjenica da se Evropa suočava sa terorizmom na svojoj teritoriji, samo su neka od pitanja koja privlače puno pažnje i troše energiju političke elite u Evropi. Sva pomenuta pitanja doživljavaju svoju kulminaciju u Srbiji.

Štaviše, Srbija se našla između velikih sila kao što su Sjedinjene Američke Države i Ruska Federacija. Iscrpljena rešavanjem ekonomskih i unutrašnjih političkih pitanja, Srbija treba da se usredsredi na sopstveni spoljnopolitički cilj i ostane na svom putu do konačnog cilja, a to je potpuni ekonomski i društveni oporavak zemlje.

Ključne reči: Republika Srbija, spoljna politika, ekonomija, politika, Evropska unija, Sjedinjene Američke Države, Ruska Federacija, bezbednost, nacionlna strategija za bezbednost 